Authors:

Annika Lindberg,

Bern University, Institute of Sociology

Fabrikstraße 8, CH - 3012 Bern

E-Mail: annika.lindberg@ soz.unibe.ch

Ph. +41316314829

Fax. +41316314817

Orcid: http://orcid.org/0000-0002-0161-0893

Lisa Marie Borrelli

Bern University, Institute of Sociology

Fabrikstraße 8, CH - 3012 Bern

E-Mail: lisa.borrelli@ soz.unibe.ch

Ph. +41316314829

Fax. +41316314817

Orcid: https://orcid.org/0000-0001-8547-320X

Biographical note

Annika Lindberg is a PhD Candidate at the Institute of Sociology, University of Bern. She holds an MSc degree in Comparative Politics from the London School of Economics and Political Science and an MSc in Political Science from Uppsala University. Her doctoral project explores the 'deportation gap' in Denmark and Sweden via an ethnography of immigration detention and 
the enforcement of deterrence policies. For the research project 'Contested Control at the Margins of the State', she has conducted additional fieldwork in Latvia and Lithuania.

Lisa Marie Borrelli is a PhD Candidate at the Institute of Sociology, University of Bern. She holds an MA degree in European Studies and a MA in Media and Communication for Development from Malmö University. For the research project 'Contested Control at the Margins of the State', she conducts ethnographic fieldwork with police and migration authorities in Italy, Switzerland, Germany, and Sweden and has further collected data in Lithuania and Latvia. In her doctoral work, she looks at ambivalent laws and emotions of streetlevel bureaucrats working on irregular migration in the Schengen Area.

A previous version of this article has been presented at the $18^{\text {th }}$ Nordic Migration Conference in Oslo, 11-12.08.2016 within the workshop 21 'Configurations of migration control'.

Acknowledgments: This research has been funded by the Swiss National Science Foundation Project No. 153225

\title{
All quiet on the Eastern Front? Controlling Transit Migration in Latvia and Lithuania
}

\begin{abstract}
While much of current debates on European border and migration control centre on the reinforcements of Europe's Southern and South-eastern borders, the Baltic States, traditionally countries of emigration to Western Europe, are experiencing their own 'crisis' in adapting their border regime to handle novel transit migration. Building on ethnographic field work on the
\end{abstract}


Lithuanian and Latvian State Border Guard Services, tasked with securing Europe's Eastern front and curtailing migrants' onward movement to Northern and Western Europe, this paper sheds light on the meanings and practices of 'borderwork' in an allegedly peripheral transit region. The article asks: How is the Baltic border regime performed by State Border Guards, what meanings do they attribute to these borders, and what can this tell us about the everchanging nature of the European border regime? We hereby seek to capture the complex landscape of de - and reterritorialised Schengen borders that for border guards mark their identity as belonging to Europe, their geopolitical distancing from Russia, and which only recently became politicised in the context of migration. The Baltic case sheds light on the variety of manifestations and meanings attributed to borders, which go beyond the mobile populations they are declared to be set up to control.

\section{Keywords}

Baltic States; migration; border control; street-level bureaucracy; policing

\section{Introduction}

If you look at the Schengen border code which is the regulation guiding most of our work, there they use the word 'illegal immigration'. Illegal immigration. But for example FRONTEX, they say irregular migration. It means that irregular comes from the attitude of the Commission, yes? That it's nicer to say irregular than illegal. And why migration instead of immigration? So, at least I'm of the opinion that when the Schengen border code was written, it was adjusted to those initial Schengen countries: Germany, France, and Benelux. So actually at that point, if you thought about migrant, in my opinion, they only immigrated into Schengen zone, that was the purpose. But 
once the Schengen zone expanded, for example Lithuania, as well as Estonia, Latvia, we are transit countries, so say the Vietnamese on the one hand immigrate, but if they are not captured, they emigrate; because they leave the country. So 'migrant' is more universal now.

(K., Lithuanian State Border Guard Service 2015)

With these words, K., a Lithuanian State Border Guard (SBG), situates Lithuania in the European border and migration regime as a country of transit for migrants who wish to move on to Western Europe. Indeed, while European border and migration control is most intensely mediatised, and even spectacularised (Andersson 2016), along a South-North migration route, Eastern European countries such as Lithuania and Latvia are experiencing their own challenges and 'crises' in reconfiguring their border regimes. The two countries are among the least popular destination countries for asylum-seekers arriving in Europe: in 2015, Lithuania received 291 asylum applications (EMN 2017), while Latvia recorded 500 irregular border crossings from Russia. This nevertheless caused Latvia to declare its own 'migration crisis' and initiate the construction of a 90 kilometre-long border fence along its entire border with Russia (P, Latvian State Border Guard (SBG) 2016; Global Detention Project 2017; Latvia Public Broadcasting 2016).

The 'borderwork' of these states is becoming an increasingly important part of their combined role as Europe's Eastern 'gatekeepers' towards Russia and as so-called transit countries for irregular migrants en route to the Schengen Area. During field visits in December 2015 and June 2016 respectively, we had the opportunity to gain first-hand insights into the unfolding of a Baltic border and migration regime as experienced through the eyes of the Lithuanian and Latvian State Border Guard Services (SBGS), who have reluctantly taken on the role as acting migration officials. This new role also requires them to 're-imagine' (Walters 2006) the borders they effectively perform. Building on these accounts, this paper sheds light 
on the experiences of State Border Guards (SBGs) in assuming the self-ascribed responsibility to 'secure' Europe's Eastern front against undesired others, while establishing themselves as geopolitical players in Europe.

The paper situates itself within the literature on migration control practices (see Guiraudon and Joppke 2001; Ellermann 2009; Eule 2014; Eule et al. 2017; Feldman 2012, 2016; Mutsaers 2015), which seeks to understand the lived and real dynamics and effects of migration control by exploring the sites and mechanisms whereby control regimes come into practice. Following this approach, we present an analysis of the work of street-level bureaucrats (see Lipsky 2010), here the Latvian and Lithuanian State Border Guard Services, using the lens of institutional ethnography (Bevir and Rhodes 2010; Fassin 2013a, b; Mutsaers 2015). Streetlevel state agents are not mere enforcers of law, but agents with their own moral subjectivity that influences their daily practices (Bigo 2014; Fassin 2013 a; Feldman 2016). Taking the 'lived experiences' of state agents seriously is therefore important not only for understanding the mechanisms of law enforcement, but also for capturing the everyday production and reproduction of borders and their effects (Parker and Vaughan-Williams 2009; Rumford 2008). With these narratives, therefore, we wish to shed light on the (re)bordering practices in an oftenoverlooked corner of Europe, which has implications not only for the migrants 'stuck in transit' on their Westbound journey, but also for our understanding of bordering practices as such.

\section{Borderwork in the 'Transit Zones' of Europe}

European borders are characterised by their selective function, which enhances the mobility of 'legitimate' travellers, while curtailing it for unwanted 'others' (Rumford 2008; Salter 2008; Mau et al. 2012). For border officials, then, their tasks more resemble that of managing liquid borders than defending solid ones (De Genova 2004; Andrijasevic and Walters 2010). As SBG K. notes when reflecting upon the State Border Guard's understanding of the term 'migration', 
the Baltic States have recent experiences both of being subjected to excluding border controls and subjects actively shaping the European polarisation of mobility rights (Mau et al. 2012: 196). In this paper, we use the analytical approach of a 'border regime', which focuses on the dynamics through which borders are produced and reproduced and thus contribute to the control of migration (Casas-Cortes et al. 2016).

The State Border Guard Services form part of these processes of "rebordering of the state" (Andreas 2003), which entails investments in border controls and numerous legal and technical developments that enhance state capacity to exert control over its borders and to spread control practices across space. These include the mobilisation of numerous security instruments, such as the deployment of guards, police forces, and the building of fences and walls, and also technology, statistics, and 'knowledge-power complexes' (Tsianos and Karakayali 2007; Walters 2006) aimed at rendering cross-border movements legible and 'manageable'. Migration, then, becomes a 'defining force in producing what the border is' (Casas-Cortes et al. 2016: 69).

Migrants entering Latvia and Lithuania are framed by state agencies as 'transit migrants', as they, according to border officials' accounts, often intend to move on to other Western or Northern European countries. The concept of transit migration, such as it has been politicised by European governments and intergovernmental agencies like the IOM, is often framed in relation to irregular migration, organized crime and human smuggling. Hence, transit migration is perceived as something to be curtailed and confined, ideally outside of Europe (Boswell and Geddes 2011; Düvell 2010); in policy documents and reports, it has served to justify the externalisation of European migration control (Andersson 2014). Collyer et al. (2014) take issue with the phenomenon, arguing that transit migration needs to be contextualised within a new geopolitical context after the fall of the USSR. Moreover, and as illustrated in the above quote by K., transit migration is far from a homogeneous or stable 
concept, but a loose category including asylum-seekers 'stuck' in onward mobility (Hess 2010), guest workers, visa overstayers, and many others. Analysing the political and discursive construction of a 'transit' zone within Europe reveals how categories of mobility are (artificially) constructed and how they come to serve different political purposes. This is also how we understand the use of 'transit zones' to describe the borderwork of Latvian and Lithuanian border officials: as a way of making sense of and assert the new role of their states, and more specifically, of the State Border Guard Service, in the reconfigured European border regime (see also Bigo 2014).

\section{Note on Methodology: Situating the Narratives of Border Guards}

In line with Bevir and Rhodes (2010: 198), we understand the state apparatus not as a unitary actor in its own right, but rather - like all political life - as 'cultural practice', which comes into being in the form of meaningful activity. Street-level agents exercise substantial discretion in interpreting laws, allocating scarce resources, and selectively enforcing complex regulations in their daily interactions with citizens and 'clients' of the state' (Lipsky 2010). In doing so, they are actively involved in 'making policy' and in (re)producing social and normative orders (Meyers and Lehmann Nielsen 2012, Eule 2014). This approach urges us to pay attention to how 'the state' and in this case, a border regime, emerges and is constantly reconfigured through the discourses and practices of situated agents (Bevir and Rhodes 2010).

The empirical basis for this article has been collected during several weeks of field research in December 2015 (Lithuania) and July 2016 (Latvia) respectively. Data collection was carried out partly through participant observation, where we shadowed State Border Guards in their daily work at different border sites, and partly through in-depth interviews with individual SBGs. In total, 11 focused, semi-structured interviews were conducted in Lithuania and around 20 interviews in Latvia, all of them in English. In order to balance officials' 
accounts, interviews were conducted with Lithuanian and Latvian NGOs, such as the Latvian Human Rights Centre, UNHCR, IOM and the Red Cross. What we hope to provide is a 'thick description' (Geertz 1973) of these agents' work-world and how their meanings and practices effectively constitute the 'borderwork' at Europe's Eastern front. During our field visits, we were granted access to SBG units at both external and internal Schengen border checkpoints, as well as to units patrolling (and hence, producing) the external and internal borders on the states' territory, including immigration detention. As all informants have been granted anonymity, we have chosen not to disclose the name of the border checkpoints but refer to them in terms of their respective functions.

In our thematic analysis (Flick et al. 2004) of the data, we found significant overlap between the Latvian and Lithuanian border guard services' understanding and practices of 'bordering' Europe's Eastern front. The similarities, rather than differences, will therefore be the focus of this analysis.

\section{Situating the Field: The Emergence of a Baltic Migration Control Regime}

Lithuania's first immigration law was introduced 1991, in response to immigration from the Soviet Union (Brake 2007). Yet according to our informants, 'the state' did not know migration as immigration until 1994, when Lithuanian authorities started recording a growing number of undocumented migrants arriving from Bangladesh, Pakistan and India (Field notes 2016). As K., a Lithuanian SBG, explained to us:

Before 1994 Lithuania had not faced irregular migration as such [...] At the time the police dealt with only small numbers of people. And the facilities at the time, yes, they were sufficient. And suddenly you had a group of ten Asian people who don't even speak English [...] but the police at the time didn't speak English either cause there was 
no need for that; more need to speak Russian. So you have people whose number was in excess of capacity to detain them in [the] police centre, you don't have language knowledge to talk to them and most importantly, it was a land of fantasy: to [deem] two days sufficient to contact the embassy of Pakistan in Denmark and get travel documents... you know what I mean. So it suddenly became clear that something different, a different solution was needed.

This is also how the Lithuanian SBGS became involved in migration control, including migration-related detention. A formerly military facility in Pabrade was converted into the 'Foreigner Registration and Detention Centre', with place for up to 1000 asylum-seekers and detainees, which developed into a permanent facility where an annual average of 260 irregular migrants are detained, and a substantial share of the yearly average of around 400 asylumseekers are housed (EMN 2015, 2017). The Lithuanian SBGS annually records around 3000 to 4000 irregular migrants who either entered, stayed, or sought to transit through the country without valid permits (EMN 2017).

Latvia's core immigration act was established in 2003. Similar to Lithuania, emigration still supersedes emigration, as many citizens leave for other European countries for better employment opportunities. Latvia has the fourth lowest rate of apprehended irregular migrants in the European Union; still, the 745 individuals detected in 2015 caused the country to declare its own 'migration crisis' (EMN 2017; Global Detention Project 2017). In 2015, 330 asylum applications were recorded (EMN 2015). The country currently has one immigration detention centre in Daugavpils, holding an annual average of 200 detainees (ibid).

Several NGO informants suggested that the inadequate reception conditions and processes were intentional in order to maintain both countries' transit status (Field notes 2015/2016). Most irregular migrants detected are Vietnamese and Georgian nationals, and 
citizens of Russian-speaking countries, who usually do not have the intention to apply for asylum (EMN 2015); yet they also record asylum-seekers from Iraq, Afghanistan, and Syria.

The SBGS in both Latvia and Lithuania are military rank and file institutions with similar competences as the police, and can be merged with the military in case of emergency. The SBGS used to operate under the Ministry of Defence but later became part of the Ministry of Interior in accordance with Schengen Regulations. Their main functions are surveillance, border checks, and risk analysis. However, much of their 'dispositions' (Lahire 2003) remain militarized: the SBGS inherit a strong military structure and hierarchy, keeping up a military drill during the education, and engaging in joint training and operations with the military and police. In both Latvia and Lithuania, we found that SBGs took particular pride in having this special, semi-military status, regardless of where they were stationed. However, the hierarchical organisation would at times also render individual SBGs vulnerable to their own institution (cf. Mutsaers 2015). Some of our SBG informants would express regret and unease after having voiced criticism about their institution, their worries possibly fuelled by the system of 'reprimands' in place for when border guards failed to fulfil their expected work tasks. Still, in comparison to the military and the police, the SBGS was presented to us as holding a relatively high status, being 'more gender equal' and, importantly, providing better job security and relatively good retirement plans, compared to other public agencies. Indeed, a few of our Latvian informants acknowledged that if it were not for the job opportunity with the SBGS, they would have migrated to Western Europe for work - just like those people whose onward mobility they were now tasked with curtailing. Hence, SBGs not only followed and implemented the political 'transit' narrative, which also justified overlooking potential longterm and settling migrants. Instead, the transit status of their respective countries was also prevalent in SBGs personal decision-making. The 'transit' status is thus performed and reproduced on the political level, as well as in daily practice. 
The Lithuanian and Latvian border regime is nowadays shaped by common European regulations and policies, including the Schengen Code, the Dublin III Regulation, the Asylum Procedures Directive, the Reception Conditions Directive, and the EURODAC, SIS and VIS systems (Vedsted-Hansen 2005; Boswell and Geddes 2011). Latvia and Lithuania also receive substantial EU funding for external border patrolling, asylum, migration and integration management, return, and 'internal security' purposes (EMN 2015; EC 2017). With their relatively new migration control functions, the SBGS have been equipped with a range of new technologies for detecting irregular border crossings, including heartbeat-detecting device and surveillance technology such as sensors, cameras and radars, indicating that their borderwork is now securitized in the context of migration (Bigo 2014). Latvian and Lithuanian SBGS also partake in FRONTEX missions and in joint patrolling session; the Latvian border guards also maintain exchanges with the European Asylum Support Office (EASO). These exchanges were presented as 'bonuses' among SBGs, and as opportunities to develop professionally.

Other exchanges with European states' border agencies were also consistently emphasised as important and a source of particular pride. SBGs shared stories of when German and Swedish border agencies had visited the Russian border to learn about external Schengen border patrolling, and were also told that Swedish migration authorities had donated beds, computers, desks, and even a mini bus that were no longer in use to the Lithuanian SBGS to refurbish the Pabrade detention centre as it was developing back in the 1990s. The funding schemes and exchanges exemplify the professional socialization of a transnational 'apparatus' (Feldman 2012) or 'assemblage' (Bigo 2014) of border management agencies who, equipped with a range of dispositions including technological, material, and legal measures, make up a border regime that then appears as commonsensical, rational and even 'humanitarian', despite the repression its bordered order produces. 


\section{Entering the Work-world of Baltic State Border Guards}

\section{Securing Schengen: From Geopolitical Borders to a Migration Control Regime}

We found that the bordered social universes that the Latvian and Lithuanian inhabit differed according to the localities and meanings associated with the different types of borders. During our field visit to external Schengen border checkpoints, we found that the borders to Russia were framed as a combination of geopolitical borders and 'biopolitical' borders targeting population movements (cf. Walters 2006). The militarisation of the border served the political purpose of demarcating 'the West' vis à vis Russia (cf. Global Detention Project 2017), but the substantial surveillance at the Russian-Lithuanian/Latvian border was also presented to us as effective for detecting and stopping transnational organised crime - and irregular migration (Field notes 2015-16). Commenting on Latvia's new $90 \mathrm{~km}$ border fence to Russia, the spokeswoman of the Ministry of Interior claimed: 'We have to talk not about fences but about fortifying Latvia's outer border, which is concurrently the EU's outer border as well' (Latvian Public Broadcasting 2016). Still, the relatively low number of border crossings and the geopolitical context in which it is situated raises suspicion that the fence rather reflects increased political tensions with Russia and the general 'rebordering' trends taking place elsewhere in Europe (Global Detention Project 2017), than an actual interest or challenge in controlling transit migration. The distancing from Russia also reflects long-lasting tensions between Latvian nationalists and the large group of ethnic Russians currently residing on Latvian territory with precarious legal status (Interview with Latvian Office of Citizenship and Migration Affairs, OCMA, 2016). Indeed, the symbolic and political distancing from their Russian neighbour was confirmed in interviews with the SBGS working in both Latvia and Lithuania, who saw their own borderwork not primarily as a task associated with migration control, but as part of a nationalist duty to secure their countries - and by extension, 'Europe' - against the 'Russian other': physically, but also value-wise. 
When talking about the neighbouring countries, two Latvian SBGs joke about Estonians as being slow, at least slower than Latvians, and that it is a common thing within the Baltic region to joke about it. "But they are our neighbours, we work well with them". Estonians are seen as more relaxed than Latvians, who are again perceived as slower and more relaxed than Lithuanians. We ask about common jokes about their other neighbours. P. thinks for a while and then says: "There is even no joke about Belarus and nothing about Russia. The situation with Russia is more difficult, it depends on the situation how much they work together [with us].”

(Field notes Latvia 2016)

Here, no jokes translate into limited overlap in (cultural) systems, which in turn inhibit the establishment of good relations. Shared values facilitate cooperation, we were told, while the lack thereof generates disassociation and distance. In relation to Russia, we understand that the absence of jokes implies a lack of common denominators and a strained relationship, reflected in the interviews. Indeed, we are also told that no information is shared by SBGs with Russian officials except in cases of emergency, and cross-border traffic is regulated on both sides by an extensive border-protection zone. Both Lithuanian and Latvian SBGs emphasised that the border control cooperation with Russia was complicated, as the 'different political systems' presented obstacles to transnational cooperation (Field notes 2015; 2016) - but also differences in their respective approach to borderwork.

Many Vietnamese crossing the border irregularly from Russia, where they do not conduct controls. They are happier that people leave Russia, and when Latvia ask to take them back they call their chief and say "da da da" on the phone and then tell us we 
cannot take that person back. Russia also works slowly, so border controls from Russia take lots of time for traffic crossing in that direction. (...) And we often discussions with the Russians on when to return irregulars there: they just deny that there were ever any footsteps to be found at their side of the border and thereby duck responsibility. And they have monitors, sensors, cameras; but this is old equipment that doesn't really work.

(A. and S., Latvian SBGS 2016)

Moreover, Lithuanian SBGs underlined their own 'humane' approach in contrast to the Russian authorities. For instance, when reflecting on an incident where a Chinese man crossed the border from Russia, SBG G. explains that Russia let him through, but when he then arrived in Lithuania they found he used false papers and refused him entry. However, the Russian officers did not take him back due to his visa not stating 'multiple entries'. According to SBG G., 'Russia does not care about the humanitarian side. The man was taken to the Registration Centre. One cannot leave someone without food, roof and warm clothes.' Yet the Russian border is not, as numbers also indicate, any 'hot spot' for irregular border activities. One Latvian SBG, P., told us that 'the most popular post to take up is at the green border cause there is nothing to do there, they just do patrols.' It seems, then, as if there was a special status associated with policing and securing Europe's external border, which had more to do with geopolitical dynamics than with migration control.

\section{'Risk Management' at the Internal Schengen Borders}

If we come in uniforms they will ask who we are and what we are doing there: 'Border guard? There is no border here!' If we appear in the city they just look at us and wonder what we're doing there. They don't know we also work with migration.

(A., Latvian SBG 2016) 
Internal Schengen borders are barely noticeable for those traveling 'legitimately' within them. Still, borders might appear 'everywhere and nowhere' (Rumford 2008) to the puzzlement of those suddenly subjected to controls. The quote by SBG A. testifies to how the changing nature of these border controls are conceived by the Latvian public. With the dismantling of internal Schengen borders, SBGs are also responsible for conducting selective controls at internal border crossing points, as well as immigration controls throughout the states' territories. Compared to the Russian border, the internal Schengen borders were characterized not so much by a defensive/offensive military strategy against 'enemies' as by logics of policing, filtering, and 'risk management' (Carrera 2007; Feldman 2012; Geiger and Pécoud 2010; VaughanWilliams 2008). At the checkpoints along the Lithuanian-Polish border, SBGS were in charge of detecting illicit cross-border traffic of humans, goods, and cars. Risk analyses, surveillance reports, and 'risk profiles' were continuously updated and shared between the neighbouring states' SBGS, and with FRONTEX, reflecting and perpetuating a language of managerial borderwork. This 'border management' was also associated with tiresome paperwork. S., a Latvian SBG, complained that 'for someone with illegal work, it takes fourteen - fourteen! papers to write a decision to issue a fine for invalid residence permit, to cite all the regulations and laws' (Fieldnotes 2016). Entering the social world of risk analysts for the sake of migration control was thus not an effortless endeavour. Yet many SBGs also found excitement in this part of work: 'It's like detective work!'

Indeed, detections of irregular migrants were presented to us as spectacular events, and something officials were proud of. Internal Schengen controls were in practice largely determined by SBGs’ discretionary power (Lipsky 2010; Mutsaers 2015; Van der Woude et al. 2017) as was explained to us at the land border checkpoint: 'In the end, controls ultimately depend on the individual border guard who's on duty. Many cars cross, and you have two 
seconds to decide which cars to stop and control...' (Fieldnotes Lithuania 2015). SBGs in both Latvia and Lithuania highlighted the need to be 'brave', to have 'sharp eyes and a sharp mind' to single out 'legitimate' travellers from 'illegal' migrants and identify forged documents (cf. Bigo 2014). 'Success stories' were shared, involving the detection of Vietnamese migrants under the floor of cars. Vietnamese nationals would usually pass through Latvia and Lithuania on their way to Poland, where they could find work in the informal sector. In the control station at the Lithuanian-Polish border, portraits of SBGs proudly posing beside detected irregular border crossers decorated the office walls. SBGs expressed both curiosity and suspicion towards 'racial others' who, as they would put it, were 'rarities' in their respective countries, due to the low immigration rates. Indeed, the selective control of border crossers was often based on stereotyping and discriminating judgements. For instance, D., a Latvian SBG selectively controlling passengers at a ferry terminal explained that controls might be carried out 'if they carry large luggage and we see anything suspicious. Or if they are black. Some might say it's racist but I do control the black people' (Field notes, July 2016). When enquiring why this is done, D. continued, 'we don't have many of them - or up until a few years ago, we didn't have many of them here. Well not only if they are black, there are other nationalities, like Kazakhs and Afghanis. They are not black but they are unusual nationalities here' (ibid.). Writing on internal Schengen border policing practices, Van der Woude et al. (2017) highlight the importance of street-level border officials' discretion for understanding crimmigration, which denotes the merging of immigration and crime control (Stumpf 2006; van der Woude 2015). Indeed, if the external Schengen borders of the Baltic States were policed in accordance with a military and geopolitical logic (cf. Walters 2006), their internal border checkpoints were primarily sites where distinctions between 'illicit' and 'legitimate' forms of mobility are made, based on racist stereotypes. Recalling the quote by Lithuanian SBG K. above, where he outlines how irregular migration suddenly became an issue warranting the 
attention of the SBGS, we might suggest that borderwork is also generated by interrelated processes of more technologies, resources, and 'power-knowledge complexes' made available to target migrant 'illegality', in turn shaping the understanding among SBGs of migration as a crime.

However, the 'crimmigration' framing was selectively applied and coexisted with other, conflicting perceptions of migrants among SBGS. For instance, in their understanding, crossing a border irregularly or remaining in the country after a visa expired were not necessarily considered as 'illegal' acts per se. Citizens from neighbouring countries, such as Russia or Belarus, who overstayed their visas after attending some festivity in Riga or Vilnius were commonly talked of as 'party folks' and not irregular migrants or criminals. Similarly, citizens from neighbouring Schengen countries living close to the border region were known to unknowingly crossing the border without valid identity documents (e.g. Latvian citizens crossing, when driving to markets from Latvia to Lithuania). These acts were not defined by SBGS as illegal: instead, the general attitude was that especially visa overstaying occurred out of pure thoughtlessness and without any intent to violate the law. Indeed, SBGs admitted that the attitude, perceived 'politeness' and intentions of irregular border crossers influenced whether and how they would be charged with illegal border crossing (Field notes Lithuania 2015). These attitudes opened up for arbitrary law enforcement practices and selective flexibility with regard to border irregularities - attitudes that clearly differed according to citizenship and race (cf. Van der Woude et al. 2017). Indeed, exceptions to the law were permitted as long they targeted the 'right' people, and anchored in the hierarchical organisation. A Latvian SBG, A., informed us that:

A general can decide to allow someone to cross a border without required documents. The chief is the only one who can decide this. For instance, a family where parents have 
passports but not the child [...]. This is in order to avoid corruption; that any individual border guard could decide on making exceptions. So instead only the chief, the general, who can. It's ok because there are so few cases.

At the same time, several among our SBG informants admitted feeling sympathy and even solidarity with some migrants, who were not too 'unlike themselves', moving to seek better opportunities in Western Europe (Field notes 2016). A Lithuanian SBG, G. suggested that 'Vietnamese are good people: calm and not noisy and willing to work - and willing to leave Lithuania as soon as possible'. Therefore, their presence was temporary and rarely visible in Latvia and Lithuania, making the task of SBGS not so much to stop immigration but to curtail onward migration to other (Schengen) countries. This brings us back to the self-ascribed marginality of the Baltic States in the European border regime. As was repeatedly stressed in interviews with SBGs, the vast majority of asylum-seekers and irregular border crossers were 'in transit'.

...Those Asian people have a goal, a vector in life. Their goal is to get to Europe. So it's easier to communicate, it's more predictable people [...], they completely understand that they got stranded. They got stuck so their next goal should be to travel back home. That's it. And they are consistent with this goal, and it made our job much easier. (K., Lithuanian SBG 2015)

$\mathrm{K}$. is here referring to people becoming 'stranded' either when detected, detained, and deported by SBGs, or because they had to leave their fingerprints in one of their Baltic States after an irregular border crossing, thus running the risk of being returned there according to the Dublin Regulation, even if they managed to move on to other European countries. The relative 
unattractiveness for asylum-seekers and the risk associated with 'getting stuck' in the Baltic states en route to Western Europe was echoed also in interviews with NGOs (including UNHCR and the Red Cross) working in both Latvia and Lithuania. If migrants do not leave (in)voluntarily, they have to apply for asylum in order to be able to stay - something which appeared as absurd to the officers. I their view, their respective countries' asylum systems offered only 'discriminating and limiting' reception conditions and poor integration models, which they assumed were among the reasons why their countries were unattractive for permanent residence (Field notes Lithuania 2015 and Latvia 2016). There were also rumours among SBGs containing information - and misinformation - of social and other benefits offered in other European 'destination countries', including Germany and the Netherlands. F., a Lithuanian SBG, recalled having heard (and believed to be true) during previous deployment in Greece that asylum-seekers in Germany receive a monthly allowance of EUR 1000; EUR 300 per child, and another EUR 1000 for furnishing their apartments. This sparked irritation among border guards: 'I would also like to claim asylum in Germany or Holland!' as one of them remarked (Field notes 2015). Following such narratives, resisting removal from a country as 'poor and hostile' as Lithuania is perceived as irrational and met with astonishment; the situation potentially facing a returnee in his or her home country not considered as part of the explanation. Hence, the SBGs had their own ways of understanding and making sense of migrants' choices.

\section{Inside Transit Detention: 'A Hotel with Special Guests'}

After people cross the border irregularly they are generally taken to Daugavpils detention centre. Many are actually happy to be put there, as they have had a difficult journey to Moscow and then onwards, and now are happy just to be in Europe and feel 
ok about going back home after about 4 weeks in detention.

(SBG A., Latvia 2016)

A similar logic could be observed among SBGs in charge with enforcing detention and deportation of undesired migrants, and was used to downplay the essentially coercive and repressive nature of these practices. Indeed, Latvia and Lithuania, immigration detention and removal procedures were presented as measures aimed at decelerating irregular migrants' onward movement, while border officers tried to redirect their trajectories. Migrants found to have crossed the border irregularly to Latvia are issued an order of removal, stating that they have to leave the country within 3 days. They are usually transported to Daugavpils Detention Centre. As reflected in the above quote by a Latvian SBG, the centre serves a deterrence function of 'motivating' irregular migrants to give up their plans of staying in Europe and 'gratefully' accept their fate of being deported to their countries of origin.

Daugavpils is a brownstone building, located in former military barracks. It contains a 'library' consisting of a couple of books, a small gym, and two small courts where detainees can move around at certain times of the day. The centre is roughly divided into two blocks, one for detained asylum-seekers and one for third-country nationals who did not apply for asylum. Women and minors are also placed in detention (Global Detention Project 2017). In contrast to the detention centre, the Asylum Centre in Mucenieki, an open facility, is operated by OCMA. Asylum-seekers can be placed here or live with family they have in Latvia as an alternative to detention, if SBGs deem there is no substantial risk that they will abscond. The SBGS, together with OCMA, is in charge of enforcing deportation orders. In contrast, only the SBGS can decide on detention: 10 days for illegal migrants, 6 days for asylum-seekers, after which a court decides on prolongation of up to a total of 18 months, in accordance with the EU Return Directive (Global Detention Project 2017). The 'transit' status of the country negatively influenced the possibilities for both refugees and detainees awaiting deportation to receive support: for 
instance, we were told that the Head of the SBGS had decided that Vietnamese nationals, who constitute one of the largest groups of detainees, should not be offered assisted voluntary return and reintegration (AVRR). According to the IOM, which is otherwise in charge of distributing such benefits, the organisation was not allowed to offer Vietnamese nationals help. Instead, the SBGS would focus on returning them by means of forced deportation, often following an extensive time period in detention (interview with IOM officer 2016).

In Lithuania, similar procedures follow: migrants apprehended without legal status are transported to the Foreigner Registration and Detention Centre in Pabrade. The Centre is a highly militarised facility, encircled by concrete walls and rows of barbed wire, and supervised and patrolled by armed border guards carrying full military uniform. At the time of our visit, it housed around 200 migrants, half of whom were categorised as asylum-seekers, the rest as 'illegal migrants'. The two groups are accommodated and 'handled' separately in a semi-open asylum centre compartment and administrative detention respectively. Asylum-seekers and irregular migrants can only be detained at the Registration Centre upon a decision by the Court or by the Migration Department. A law passed in 2012 permits border guards to detain asylumseekers as way of preventing them from leaving Lithuania after registration (EMN and IOM 2014). According to SBGs, the law was adopted in response to migrants' strategy to apply for asylum in order to be released from detention and pursue their journey to other European countries. The 'transit migration' logic is thus reflected in the legislation.

Despite the military dispositions that characterise the detention centres, SBGs framed their role there as administrative and even socially oriented. Lithuanian SBGs explained that they appreciated having more regular, long-term personal contact with detainees confined in the centre. The same applied to Latvia. Indeed, all administrative tasks related to the case or personal circumstances of each individual detainee were administered by one and the same SBG official, which our informants found to be a good arrangement, since it allowed for them 
to 'build trust' and a 'personal relationship' with detainees. It was also assumed to render deportations more efficient, as officers would have the opportunity to 'motivate' detainees to return in the course of their daily interactions. Lithuanian SBG F. (2015) explained how he, inspired by practices he had heard were used in the Netherlands, would let detainees tell positive stories of their home countries, hence 'making them think of their return in more optimistic terms'. The assumed temporariness and transitory nature of migration to Lithuania further enabled border guards to construct a narrative of 'shared goals' with detainees and deportees: namely, the speedy and smooth return to their countries of origin.

The coercive, repressive nature of their work was thus downplayed. Indeed, while our NGO informants (2015) questioned the prevalence of such 'humane' or 'empathetic' (cf Hall 2010) attitudes among border guards, pointing to their inexistent training and limited experience of working with vulnerable groups, the narrative of shared interests seemed to function as a coping strategy for officials. The ethical challenges of working inside detention were admitted by one informant (SBG F 2015), who explained that, when asked about his job by friends and family, he would reply that he works at 'a hotel with very special guests', or, alternatively, 'at the government's travel agency, where they only provide one-way tickets'. This narrative of uncomplicatedly 'waving people goodbye at the airport' sustains the idea of an essentially humane and efficient migration control regime, or at least suggests a process of creating distance and denouncing personal responsibility for a job that can be troubling (see Fassin 2011; Feldman 2012; Hall 2010).

As also acknowledged by SBGs, detention served a deterrence function in the Baltic border regime (Detention Watch Network 2015). As a Lithuanian SBG put it: 'returnees can then tell others how bad it is in Lithuania'. This was clearly reflected in the facilities and in the attempts by SBGs to 'motivate' detainees to return. The narratives of shared interests and the emphasis on the 'social' aspects of their work in detention mirror the simultaneous penal- and 
care taking logic that applies to detention centres across Europe (Bosworth and Turnbull 2014). Furthermore, and somewhat counter intuitively, the detention centres in Lithuania and Latvia highlight the permeability of borders. While SBGs emphasised the narrative of a 'shared goal of return' between themselves and detainees, they were also well aware that deportation did by no means constitute the end of the migrants' journey (cf. Khosravi (ed.) 2017; Schuster and Majidi 2013). Instead, the Baltic examples illustrate how detention and deportation rather contributes to reproducing circular migratory movements. Moreover, the self-ascribed status as transit states renders migrants 'stuck in transit' in a double sense: not only are they subjected to confinement and forced deportation, but their 'failure' to reach Western Europe also serves as a justification for their deportation, as it is considered by state officials as a better option than staying in the Baltic States. The detention centres and deportation processes hence serve the purpose of redirecting migrants' journeys back to their assumed countries of origin, so that they can then embark on a new journey to Europe (Field notes 2015, 2016). Indeed, this narrative also enabled SBGs to denounce responsibility for the pains of detention and deportation.

\section{Conclusion}

This paper has been interested in how a border regime comes into being and evolves through the narratives and practices of the state officials tasked with (selectively) enforcing it. We found that Latvian and Lithuanian SBGS shouldered their relatively new - and increasingly politicised - tasks of migration control with mixed feelings and insecurity over practices. These were expressed through narratives of simultaneous criminalisation, fascination, and at times ad hoc solidarity for the migrants stuck in transit on their Westbound journey; including the "hotel guests' in administrative detention, and the asylum-seekers critically ogled for refusing compliance with the SBGs' expectation of their stay being only temporary. Indeed, SBGs work in conducting border checks and surveillance balanced between military organization and 
dispositions, selective criminalisation of 'border transgressors', and other, more ambivalent attitudes, indicating that the border remains a space for asymmetric negotiation (Casas Cortes et al. 2016). Their narratives draw our attention to the diverse and ever-shifting configurations of the European border regime, where borderwork comes to serve a variety of purposes that extend beyond migration control.

Indeed, Balibar (2009) has highlighted the 'polysemic' nature of borders and the different experiences and meanings attached to them. In this paper, we have shown how the multifaceted borders at 'Europe's Eastern front' acquired a variety of meanings, ranging from geopolitical, to managerial - and biopolitical (cf. Bigo 2014; Walters 2006). For Baltic SBGs, the repoliticised borderwork in relation to migration was seen an opportunity to assert their place within rather than on the fringes of Europe. Still, in framing Latvia and Lithuania as transit countries, SBGs effectively produced transitory subjects (cf. Collyer et al. 2010), which enabled narratives of 'shared interests' with the individuals they were tasked with controlling, and also served as justification for denouncing responsibility for the destiny of those whose journeys were violently interrupted by their borderwork. Thus, downplaying the essentially coercive nature of border controls, the SBGs reproduced an image of the Baltic states as transit zones for migrants who, 'not unlike themselves', sought better opportunities in Western Europe.

Importantly, these narratives become real in their effects for migrants apprehended in these reconfigured border controls: the 'transit zone' remains an in-between place, where migrants are held on the fringes of 'European' territory, included only by their exclusion. Yet the perspectives of the SBGs also highlight how borderwork serves a variety of functions beyond migration control, notably as productive sites of (re)imagining the political, territorial, and narrative boundaries of Europe.

\section{Bibliography}


Andersson, R. 2016. “Europe's failed 'fight' against irregular migration: Ethnographic notes on a counterproductive industry." Journal of Ethnic and Migration Studies 42 (7): 1055 1075. doi: 10.1080/1369183X.2016.1139446

Andersson. R. 2014. "Time and the Migrant Other." American Anthropologist 116 (4): 1-15. doi: 10.1111/aman.12148

Andreas, P. 2003. Border Games. Policing the U.S.-Mexico Divide. Ithaca and London: Cornell University Press.

Andrijasevic, R. and W. Walters. 2010. "The International Organisation for Migration and the International Government of Borders." Environment and Planning D: Society and Space, 28 (6): 977-999. doi: 10.1068/d1509

Balibar, E. 2009. "Europe as Borderland." Environment and Planning, Society and Space 27: 190-215. doi: 10.1068/d13008

Bevir, M. and R.A.W. Rhodes. 2010. The State as Cultural Practice. Oxford: Oxford University Press.

Boswell, C. and A. Geddes. 2011. Migration and Mobility in the European Union. European Union Series. Basingstoke: Palgrave Macmillan. https://www.files.ethz.ch/isn/31387/CP004\%20The\%20Changing\%20Landscape.pdf

Bigo, D. 2014. "The (in)securitization Practices of the Three Universes of EU Border Control: Military/Navy - Border Guards/Police - Database Analysts". Security Dialogue 45 (3): 209-225. doi: 10.1177/0967010614530459

Bosworth, M. and S. Turnbull. 2014. Immigration Detention and the Expansion of Penal Power in the UK. (Forthcoming) In Extraordinary Punishment: An Empirical Look at Administrative Black Holes in the United States, the United Kingdom, and Canada, edited by K. Reiter and A. Koenig. Palgrave; Criminal Justice, Borders and Citizenship $\begin{array}{lllll}\text { Research Paper Nor } & \text { Nocessed } 29 & \text { December } & \end{array}$ http://papers.ssrn.com/sol3/papers.cfm?abstract_id=2458343

Brake, B. 2007. "Integration of Foreigners and Ethnic Minorities." Bundeszentrale for $\begin{array}{lllll}\text { politische } & \text { Bildung. } & \text { Accessed } & 29 & \text { December }\end{array}$ http://www.bpb.de//gesellschaft/migration/Dossier-migration/58435

Carrera, S. 2007. "The EU border management strategy: FRONTEX and the challenges of irregular immigration in the Canary Islands." Brussels: Centre for European Policy Studies. CEPS Working Document 261. Doi: 10.2139/ssrn.1338019. Accessed 2 January 2018. https://ssrn.com/abstract=1338019

Casas-Cortes, M.; Cobarrubias, S.; De Genovy, N.; Garelli, G.; Grappi, G.; Heller, C.; Hess, S.; Kasparek, B.; Mezzadra, S.; Neilson, B.; Peano, I.; Pezzani, L.; Pickles, J.; Rahola, F.; Riedner, L.; Scheel, S.; Tazzioli, M. 2014. "New Keywords: Migration and Borders." Cultural Studies 29 (1): 55-87. doi: 10.1080/09502386.2014.891630

Collyer, M., Düvell, F., de Haas, H. and Molodikova, I. 2014. "Transit Migration and European Spaces." In Transit Migration in Europe, edited by Düvell, F.; Molodikova, I. and Collyer, M., 13-36. Chicago: University of Chicago Press.

Collyer, M., Düvell, F. and de Haas, H. 2010. "Critical Approaches to Transit Migration." Journal of Population, Space and Place 18 (4): 407-414. doi: 10.1002/psp.630

De Genova, B. 2004. "The Legal Production of Mexican/Migrant 'Illegality'." Latino Studies 2 (2): 160-185. doi: 10.1057/palgrave.lst.8600085

Detention Watch Network. 2015. Ending the Use of Immigration detention to Deter Migration. $\begin{array}{lllll}\text { April 2015. } & \text { Accessed } & 23 & \text { January }\end{array}$ https://www.detentionwatchnetwork.org/sites/default/files/reports/DWN\%20Detentio n\%20as\%20a\%20Deterrance\%20Policy\%20Brief.pdf

Düvell, F. 2010. "Transit migration: A blurred and politicised concept." Population, Space and Place 18 (4): 415-427. doi: 10.1002/psp.631 
Ellermann, A. 2009. States Against migrants: Deportation in Germany and the United States. Cambridge: Cambridge University Press.

EMN and IOM. 2014. "The Use of Detention and Alternatives to Detention in Lithuania". EMN Focussed Study. Accessed 29 December 2017. http://ec.europa.eu/dgs/homeaffairs/what-we-do/networks/european_migration_network/reports/docs/emnstudies/emn_detention_and_alternatives_to_detention_2013_en.pdf

EMN. 2015. "Country Fact Sheet: Lithuania 2015." Accessed 29 December 2017. https://ec.europa.eu/home-affairs/sites/homeaffairs/files/what-wedo/networks/european_migration_network/reports/docs/countryfactsheets/17_lithuania_country_factsheet_2015.pdf

EMN. 2017. “Lithuania: General Trends”. Accessed 29 December 2017. http://123.emn.lt/en/\#migration-trends

Eule,, T.G., Loher, D. and Wyss, A. 2017. "Contested control at the margins of the state." Journal of Ethnic and Migration Studies: 1-13. doi: 10.1080/1369183X.2017.1401511

Eule, T. 2014. Inside Immigration Law: Migration Management and Policy Application in Germany. Farnham: Ashgate.

European Commission (EC). 2017. "Internal Security Fund - Borders and Visa”. Accessed 29 December 2017. https://ec.europa.eu/home-affairs/financing/fundings/security-andsafeguarding-liberties/internal-security-fund-borders_en

Fassin, D. 2013 a. Enforcing Order: An Ethnography of Urban Policing. Cambridge: Polity.

Fassin, D. 2013 b. "A case for critical ethnography. Rethinking the early years of the AIDS epidemic in South Africa." Social Science \& Medicine 99: 11-126. doi: 10.1016/j.socscimed.2013.04.034

Fassin, D. 2011. "Policing borders, producing boundaries. The governmentality of immigration in dark times." The Annual Review of Anthropology 40: 213-226.

Feldman, G. 2012. The Migration Apparatus: Security, Labor, and Policymaking in the European Union. Stanford: Stanford University Press.

Feldman, G. 2016. "'With my head on the pillow': Sovereignty, Ethics, and Evil among Undercover Police Investigators." Comparative Studies in Society and History 58 (2): 491-518. doi: 10.1017/S0010417516000153

Flick, U., von Kardoff, E. and I. Steineke (eds.). 2004. A Companion to Qualitative Research. London: Sage Publications Ltd.

Geertz, C. 1973. The Interpretation of Cultures: Selected Essays. New York: Basic Books.

Geiger, M. and A. Pecoud. 2010. The Politics of International Migration Management. Migration, Minorities and Citizenship. Basingstoke: Palgrave Macmillan.

Global Detention Project. 2017. "Latvia Immigration Detention Profile”. Accessed 7 January 2018. https://www.globaldetentionproject.org/countries/europe/latvia

Guiraudon, V. and C. Joppke (Eds.). 2001. Controlling a New Migration World. London and New York: Routledge.

Hall, A. 2010. 'These People Could Be Anyone': Fear, Contempt (and Empathy) in a British Immigration Removal Centre". Journal of Ethnic and Migration Studies: 36 (6): 88198.

Hess, S. 2010. “'We are facilitating States!' An Ethnographic Analysis of the ICMPD.” In The Politics of International Migration Management. Migration, Minorities and Citizenship, edited by Geiger M. and Pécoud A. London: Palgrave Macmillan, 96-118. doi: 10.1057/9780230294882_5

Khosravi, S. (ed.). 2017. After Deportation - Ethnographic Perspectives. London : Palgrave Macmillan.

Lahire, B. 2003. "From the Habitus to an Individual Heritage of Dispositions. 
Towards a Sociology at the Level of the Individual". Poetics 31: 329-355. doi : 10.1016/j.poetic.2003.08.002

Latvian Public Broadcasting 2016. Accessed 2 January 2018. https://www.linkedin.com/pulse/public-broadcasting-latvia-sonya-silina/

Lipsky, M. 2010. Street-Level Bureaucracy: Dilemmas of the Individual in Public Services. New York: Russell Saga Foundation.

Mau, S., H. Brabandt, L. Laube and C. Roos. 2012. Liberal States and the Freedom of Movement: Selective Borders, Unequal Mobility. Basingstoke: Palgrave Macmillan.

Meyers, M.K. and Lehmann Nielsen, V. 2012. "Street-Level Bureacrats and the Implementaion of Public Policy." In The SAGE Handbook of Public Administration, edited by Peters, G. and Pierre, J. 305-318. London: SAGE Publications Ltd. doi: 10.4135/9781446200506.n20

Mutsaers, P 2015. A public anthropology of policing: Law enforcement and migrants in the Netherlands. Ph.D. Tilburg University. Accessed 2 January 2017. https://pure.uvt.nl/portal/files/6872568/Mutsaers_Public_12_06_2015.pdf

Parker, N. and Vaughan-Williams, N. 2009. "Lines in the Sand? Towards an Agenda for Critical Border Studies." Journal of Geopolitics 14 (3): 582-587. doi: 10.1080/14650040903081297

Rumford, C. 2008. Citizens and Borderwork in Contemporary Europe. London: Routledge.

Salter, M. 2008. "When the Exception Becomes the Rule: Borders, Sovereignty, and Citizenship", Citizenship Studies 12 (4): 365-380. doi: 10.1080/13621020802184234

Schuster, L., and Majidi, N. 2013. "What Happens Post-Deportation? The Experience of Deported Afghans." Migration Studies 1 (2): 221-40. doi: 10.1093/migration/mns011

Stumpf, J. 2006. "The Crimmigration Crisis: Immigrants, Crime, and Sovereign Power." American University Law Review 56 (2). Accessed 2 January 2018. http://digitalcommons.wcl.american.edu/cgi/viewcontent.cgi?article=1274\&context=a ulr

Tsianos, V. and Karakayali, S. 2010. "Transnational Migration and the emergence of the European Border Regime: An Ethnographic Analysis." European Journal of Social Theory 13 (3): 373-387. doi: 10.1177/1368431010371761

Vaughan-Williams, N. 2008. "Borders, Territory, Law." International Political Sociology 2 (4): 322-338. doi: 10.1111/j.1749-5687.2008.00054.x

Vedsted-Hansen, J. 2005. "Common EU Standards on Asylum - Optional Harmonisation and Exclusive Procedures?" In The First Decade of EU Migration and Asylum Law, edited by Guild, E. and Minderhoud, P. 255-271. Martinus Nijhoff Publishers, Leiden, Immigration and Asylum Law and Policy in Europe, Vol. 24.

Woude, M. van der; Barker, V. and Leun, J. van der. 2017. "Framing migration and the process of crimmigration: A systematic analysis of the media representation of unauthorized immigrants in the Netherlands." European Journal of Criminology 14 (1): 110-119. doi: $10.1177 / 1477370816640136$

Woude, M., van der. 2015. The Dutch Response to the Refugee Crisis. Border Criminologies Blog (16 September 015). Accessed 29 December 2017. https://www.law.ox.ac.uk/research-subject-groups/centre-criminology/centrebordercriminologies/blog/2015/09/dutch-response

Walters, W. 2006. "Border/Control." European Journal of Social Theory 9 (2): 187204.doi: $10.1177 / 1368431006063332$ 